\begin{tabular}{c|c|c}
\hline \hline & DISEASES OF AQUATIC ORGANISMS & Dis Aquat Org \\
Vol. 61: $67-73,2004$ & Published October 21 \\
\hline \hline
\end{tabular}

\title{
Strain variation and geographic endemism in Streptococcus iniae
}

\author{
H. Kvitt*, A. Colorni \\ Israel Oceanographic and Limnological Research, National Center for Mariculture, PO Box 1212, Eilat 88112, Israel
}

\begin{abstract}
Twenty-six Israeli isolates of Streptococcus iniae from both marine and fresh/brackish water sources were compared with each other and with 9 foreign isolates. All the isolates were tentatively identified according to their biochemical profile. Direct sequencing of approximately $600 \mathrm{bp}$ PCR products of the 16S rDNA confirmed their identification as $S$. iniae at the molecular level and revealed a new (one-nucleotide) variant among Israeli isolates, in addition to 2 variants that had been previously reported. Strain variation was further examined by subjecting the isolates to randomly amplified polymorphic DNA (RAPD) and amplified fragment length polymorphism (AFLP) analyses. The RAPD method allowed separation of the isolates into only 2 groups, one including 5 Israeli fresh/brackish water isolates and one including all the other isolates. The AFLP method grouped the Israeli marine isolates into one homogeneous cluster, although they had been obtained in different years (1995 to 2001) from different species of fish, and from wild (Red Sea) as well as cultured (both Mediterranean and Red Sea) sources. The Israeli fresh/brackish water isolates and foreign isolates separated into distinct entities that clustered at generally high degrees of similarity. The distance between the clusters of the Israeli marine and fresh/brackish water isolates indicates that the $S$. iniae streptococcosis that has been afflicting the aquaculture industries in the 2 environments in recent years was caused by distinct strains. AFLP showed superior discriminative properties over RAPD in detecting intraspecific variation and proved to be an important tool for the characterization of $S$. iniae. A correlation between strain variation and geographic endemism was established.
\end{abstract}

KEY WORDS: Streptococcus $\cdot$ Strain variation $\cdot$ Identification $\cdot 16 \mathrm{~S}$ rDNA $\cdot$ RAPD $\cdot$ AFLP $\cdot$ Endemism $\cdot$ Epidemiology

Resale or republication not permitted without written consent of the publisher

\section{INTRODUCTION}

Streptococcus spp. have been recently listed among the emerging problems in aquaculture (Austin 1999) and Streptococcus iniae is recognized as one of the most dangerous members of this genus, causing lethal infections in both freshwater and marine fish (Berridge et al. 1998, Bromage \& Owens 2002). Fish farms in many parts of the world have suffered serious economic losses due to this bacterial pathogen (Kusuda \& Komatsu 1978, Kitao 1993, Austin \& Austin 1999). The epidemiology of the disease, however, remains elusive. In Israel, streptococcosis caused by $S$. iniae appeared for the first time in 1986 and rapidly spread throughout the country, affecting cultures of tilapia and rainbow trout (Eldar et al. 1994, 1995). In the Eilat (Red Sea) region, $S$. iniae was first diagnosed in 1996 in cultured red drum and has recurred repeatedly in Israeli mariculture ever since (Colorni et al. 2002). S. iniae has also been detected in marine fish from the wild (Zlotkin et al. 1998, Ferguson et al. 2000, Colorni et al. 2002). Infection by $S$. iniae generally develops into septicemia, but clinical signs, pathology and virulence of the disease vary in different hosts (Fuller et al. 2001, Colorni et al. 2002). The Israeli $S$. iniae isolates from both freshwater and marine environments share a similar biochemical profile (Colorni et al. 2002). The purpose of this study was to compare isolates at the molecular level to determine if intraspecific variants could be found among isolates from different geographical locations or from the 
same region but in different hosts and years of isolation, thus shedding some light on the epidemiology of the disease. Because $S$. iniae also appears to be able to infect higher vertebrates including humans (Weinstein et al. 1997), the medical implications with regard to the ability to discriminate among different strains are of great importance.

\section{MATERIALS AND METHODS}

Bacterial isolates. A total of 35 isolates from different hosts, years of isolation, geographic regions and aquatic environments were used. The sources are summarized in Table 1. The first marine case of Streptococcus iniae in Israel was diagnosed in 1995 in a stock of European sea bass Dicentrarchus labrax submitted to our laboratory for examination from a fish farm in Ashdod, on the Mediterranean coast of Israel (s1). Subsequent cases (s2-s10, s13-s16, s19-s20, s44) refer to fish grown in the Eilat area (Red Sea). The tilapia Oreochromis mossambicus (s4), adapted to seawater, were maintained at the National Center for Mariculture, Israel, for experimental purposes. The striped piggy Pomadasys stridens (Pomadasyidae) (s11), the lizardfish Synodus variegatus (Synodontidae) (s12) and the lyretail grouper Variola louti (Serranidae) (s26) were wild fish, collected moribund or freshly dead in shallow waters in the Gulf of Eilat. Three Israeli isolates were obtained from tilapia (s29, s41) and striped bass (s42) cultured in brackish water; 6 Israeli isolates originated from rainbow trout (s36, s39, sD15, s173, s206, s404) cultured in freshwater. Eight foreign piscine isolates originating from the USA (s17, s21), Australia (s27), Japan (s28) and the Barbados islands (s31-s34), and a human isolate from Canada (s18) were also included (see 'Acknowledgements'). S. iniae ATCC (American Type Culture Collection) type strain 29178 was used as reference in both RAPD and AFLP reactions.

Bacteriological methods. Bacteriological methods for the isolation, culture, and biochemical identification of Streptococcus iniae were as described by Colorni et al. (2002). Briefly, tryptic soy agar (TSA) (Difco) prepared with $25 \%$ aged seawater supplemented with $5 \%$ outdated human blood-bank blood, and an incubation temperature of $24 \pm 1^{\circ} \mathrm{C}$ were used for culture. Presumptive identification of the isolates was made using 2 commercial kits: API 20 Strep and API $50 \mathrm{CH}$ (BioMérieux). Manufacturers' instructions were followed except for the incubation temperature, which was maintained at $24 \pm 1^{\circ} \mathrm{C}$ instead of the recommended $36 \pm 1^{\circ} \mathrm{C}$, and the intermediate readings, which were not taken before $18 \mathrm{~h}$. Final results were read $72 \mathrm{~h}$ after inoculation and compared with the biochemical profiles described by Eldar et al. (1994).

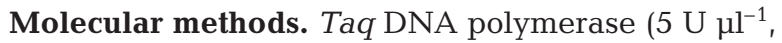
Promega) was used for all amplification procedures. T4 polynucleotide kinase, T4 ligase and restriction endonucleases were supplied by New England Biolabs. As a molecular weight marker, AmpliSize ${ }^{\mathrm{TM}}$ molecular ruler (Bio-Rad) was used.

DNA extraction. Five mg of pure fresh bacterial cultures were ground gently on ice with $300 \mu$ of grinding buffer (100 mM Tris-HCl pH 9, 100 mM EDTA, 1\% sodium dodecyl sulphate [SDS]). The homogenate was incubated at $70^{\circ} \mathrm{C}$ for $30 \mathrm{~min}$. Forty-two $\mu$ l of $8 \mathrm{M}$ potassium acetate was then added and the tube was gently mixed for $1 \mathrm{~min}$. The sample was placed on ice for $30 \mathrm{~min}$, then centrifuged at $4^{\circ} \mathrm{C}, 12000 \mathrm{rpm}(15300$ $\times g$ ) for $15 \mathrm{~min}$. The supernatant was immediately transferred into a fresh tube and again centrifuged at $4^{\circ} \mathrm{C}, 12000 \mathrm{rpm}$ for $5 \mathrm{~min}$. The centrifugation step was repeated until no traces of pellet were visible. DNA was precipitated with 1 volume of isopropanol for $15 \mathrm{~min}$ at room temperature. Pelleted DNA was washed in $70 \%$ ethanol and resuspended in $40 \mu \mathrm{l}$ deionized distilled water $\left(\mathrm{ddH}_{2} \mathrm{O}\right)$. DNA quality was assessed by electrophoresis in a $0.7 \%$ agarose gel and ethidium bromide staining. DNA quantity and purity (260:280 ratio) were also estimated using an RNA:DNA Calculator (Gene Quant pro).

PCR and 16S rDNA sequencing. The primers utilized in this study were R518 (5'-CAGCAGCCGCGGTAATAC-3') and UNI3 (Kvitt et al. 2002) (positions 519 to 536 and 1395 to 1413 according to the Streptococcus iniae 16S rDNA sequence, GenBank accession no. AF335572). Of the expected 884 bp PCR product, a variable region of approximately $600 \mathrm{bp}$ (Bachrach et al. 2001) was sequenced using primer R518.

PCR was performed with a Programmable Thermal Controller (PTC-100 ${ }^{\mathrm{TM}}$, MJ Research). A typical $50 \mu \mathrm{l}$ reaction mixture contained 50 to 100 ng DNA, 1 U Taq DNA polymerase, $0.25 \mu \mathrm{M}$ primer, $0.2 \mathrm{mM}$ dNTPs, $50 \mathrm{mM} \mathrm{KCl}, 1.5 \mathrm{mM} \mathrm{MgCl}, 10 \mathrm{mM}$ Tris-HCl (pH 8.8), $0.1 \%$ (vol/vol) Triton X-100. Typical cycling parameters were: $1 \mathrm{~min}$ denaturation $\left(94^{\circ} \mathrm{C}\right), 1 \mathrm{~min}$ annealing $\left(50^{\circ} \mathrm{C}\right)$ and $1.5 \mathrm{~min}$ extension $\left(72^{\circ} \mathrm{C}\right)$ for 30 cycles. The reaction was started by a denaturation step (3 min at $94^{\circ} \mathrm{C}$ ) and ended with a 5 min extension step at $72^{\circ} \mathrm{C}$. For the sequencing reaction, double-stranded PCR products were purified using a PCR purification kit (Qiagen); $50 \mathrm{ng}$ of DNA template was used for each reaction. Templates were sequenced using an Automated DNA Sequencer (Perkin Elmer, model 377) and the Big Dye Terminator from ABI Cycle Sequencing Kit. Resulting nucleotide sequences were compared with those deposited in GenBank.

RAPD. For RAPD, the primer p14 (5'-GATCAAGTCC) (Gardiner et al. 1995, Bachrach et al. 2001) was selected. A typical 50 ml PCR mixture con- 
Table 1. Streptococcus iniae isolates utilized in the study. Clusters according to 16S rDNA sequences (GenBank accession numbers are indicated by Roman numerals, I: AF335572; II: AY260834; III: AF335573), RAPD patterns (1: 3 RAPD products; 2: 4 RAPD products. See Fig. 1, Lanes 1 and 2, respectively), and AFLP analysis (O.C. [A-D]: outcast from Clusters A to D; O.C. [A-E]: outcast from Clusters A to E. See Fig. 2)

\begin{tabular}{|c|c|c|c|c|c|c|}
\hline Isolate code & Date & Host & Origin & $16 \mathrm{~S}$ & RAPD & AFLP \\
\hline s1 & 1995 & Dicentrarchus labrax & Israel, Ashdod, Med Sea (pond) & I & 2 & $\mathrm{~A}$ \\
\hline s2 & 1996 & Sciaenops ocellatus & Israel, Eilat, Red Sea (cage) & I & 2 & A \\
\hline s4 & 1998 & Oreochromis mossambicus & Israel, Eilat, Red Sea (tank) & I & 2 & $\mathrm{~A}$ \\
\hline s5 & 1998 & Sciaenops ocellatus & Israel, Eilat, Red Sea (cage) & I & 2 & A \\
\hline s8 & 1999 & Sciaenops ocellatus & Israel, Eilat, Red Sea (cage) & I & 2 & A \\
\hline s9 & 2000 & Sciaenops ocellatus & Israel, Eilat, Red Sea (cage) & I & 2 & $\mathrm{~A}$ \\
\hline s10 & 2000 & Sciaenops ocellatus & Israel, Eilat, Red Sea (cage) & I & 2 & A \\
\hline s11 & 2000 & Pomadasys stridens & Israel, Eilat, Red Sea (wild) & I & 2 & A \\
\hline s12 & 2000 & Synodus variegatus & Israel, Eilat, Red Sea (wild) & I & 2 & $\mathrm{~A}$ \\
\hline s13 & 2000 & Dicentrarchus labrax & Israel, Eilat, Red Sea (pond) & I & 2 & $\mathrm{~A}$ \\
\hline s14 & 2000 & Dicentrarchus labrax & Israel, Eilat, Red Sea (cage) & I & 2 & $\mathrm{~A}$ \\
\hline s16 & 2001 & Dicentrarchus labrax & Israel, Eilat, Red Sea (cage) & I & 2 & $\mathrm{~A}$ \\
\hline s17 (97057) & 1997 & Oreochromis niloticus & USA, New York State & I & 2 & $\mathrm{C}$ \\
\hline s18 (9117) & 1996 & Human & Canada & I & 2 & $\mathrm{D}$ \\
\hline s19 & 2001 & Dicentrarchus labrax & Israel, Eilat, Red Sea (tank) & I & 2 & $\mathrm{~A}$ \\
\hline s20 & 2001 & Lates calcarifer & Israel, Eilat, Red Sea (pond) & I & 2 & A \\
\hline s21 (ARS-TN-NDS10) & 1998 & Oreochromis niloticus & USA, North Dakota & I & 2 & $\mathrm{D}$ \\
\hline s26 & 2001 & Variola louti & Israel, Eilat, Red Sea (wild) & I & 2 & A \\
\hline s27 & 1999 & Lates calcarifer & $\begin{array}{l}\text { Australia, Cardwell, brackish water } \\
\text { (cage) }\end{array}$ & I & 2 & O.C. $(A-D)$ \\
\hline s28 (NUF631) & 1992 & Paralichthys olivaceus & Japan (tank) & I & 2 & $\mathrm{E}$ \\
\hline s29 & 1901 & Oreochromis sp. & $\begin{array}{l}\text { Israel, Ein Yahav, brackish water } \\
\text { (pond) }\end{array}$ & II & 2 & O.C. (A-D) \\
\hline s31 & 1999 & Ocyurus chrysurus & Barbados, Caribbean Sea (wild) & I & 2 & $\mathrm{~B}$ \\
\hline s32 & 1999 & Haemulidae (grunt) & Barbados, Caribbean Sea (wild) & I & 2 & $\mathrm{~B}$ \\
\hline s33 & 1999 & Haemulidae (grunt) & Barbados, Caribbean Sea (wild) & I & 2 & $\mathrm{~B}$ \\
\hline s34 & 1999 & Scaridae (chub) & Barbados, Caribbean Sea (wild) & I & 2 & $\mathrm{~B}$ \\
\hline s36 & 1996 & Oncorhynchus mykiss & $\begin{array}{l}\text { Israel, Upper Galilee, freshwater } \\
\text { (raceway) }\end{array}$ & III & 1 & $\mathrm{~F}$ \\
\hline s39 & 2001 & Oncorhynchus mykiss & $\begin{array}{l}\text { Israel, Upper Galilee, freshwater } \\
\text { (raceway) }\end{array}$ & III & 1 & F \\
\hline s41 & 2002 & Oreochromis sp. & $\begin{array}{l}\text { Israel, Neot haKikar, } \\
\text { brackish water (raceway) }\end{array}$ & II & 2 & O.C. (A-D) \\
\hline s42 & 2002 & Morone saxatilis & $\begin{array}{l}\text { Israel, Ein Tamar, } \\
\text { brackish water (raceway) }\end{array}$ & I & 2 & $\mathrm{E}$ \\
\hline s44 & 2002 & Dicentrarchus labrax & Israel, Eilat, Red Sea (cage) & I & 2 & $\mathrm{~A}$ \\
\hline sD15 (DAN 15) & 1992 & Oncorhynchus mykiss & $\begin{array}{l}\text { Israel, Upper Galilee, } \\
\text { freshwater, (raceway) }\end{array}$ & III & 2 & $\mathrm{C}$ \\
\hline s173 (KFP 173) & 1997 & Oncorhynchus mykiss & $\begin{array}{l}\text { Israel, Upper Galilee, } \\
\text { freshwater (raceway) }\end{array}$ & III & 1 & F \\
\hline s206 (KFP 206) & 1999 & Oncorhynchus mykiss & $\begin{array}{l}\text { Israel, Upper Galilee, } \\
\text { freshwater (raceway) }\end{array}$ & III & 1 & $\mathrm{~F}$ \\
\hline s404 (KFP 404) & 2000 & Oncorhynchus mykiss & $\begin{array}{l}\text { Israel, Upper Galilee, freshwater } \\
\text { (raceway) }\end{array}$ & III & 1 & F \\
\hline ATCC $29178^{\mathrm{T}}$ & 1972 & Inia geoffrensis (dolphin) & $\begin{array}{l}\text { USA, San Francisco, freshwater } \\
\text { (captive) }\end{array}$ & I & 2 & O.C. (A-E) \\
\hline
\end{tabular}

tained $50 \mathrm{mM} \mathrm{KCl}, 10 \mathrm{mM}$ Tris- $\mathrm{HCl}(\mathrm{pH} 8.8), 1.5 \mathrm{mM}$ $\mathrm{MgCl}_{2}, 0.1 \%$ (vol/vol) Triton X-100, $200 \mathrm{mM}$ dNTPs, 50 pmol primer, 2 U Taq DNA polymerase (Promega), and 20 to 50 ng DNA. The amplification cycles were as described by Neeman et al. (1998) for Streptococcus strains. Amplified DNA fragments were separated by electrophoresis in $1.5 \%$ agarose gel and visualized by ethidium bromide staining. The gels were photographed and the RAPD patterns of the isolates were compared.
AFLP. Restriction enzyme digests, adapter annealing, and amplification procedures were performed as described by Vos et al. (1995) with the following modifications: $500 \mathrm{ng}$ genomic DNA was digested with $20 \mathrm{U}$ EcoRI and $5 \mathrm{U}$ MseI restriction endonucleases for $3 \mathrm{~h}$ at $37^{\circ} \mathrm{C}$. Preamplification was performed with the AFLP adapters: EcoRI-adapter: 5'-CTCGTAGACTGCTACC (E1) and MseI-adapter: 5'-GACGATGAGTCCTGAG (M1). The cycling parameters were: denaturation step $\left(2 \mathrm{~min}\right.$ at $94^{\circ} \mathrm{C}$ ) followed by 19 cycles of $30 \mathrm{~s}$ denatura- 
tion $\left(94^{\circ} \mathrm{C}\right), 30 \mathrm{~s}$ annealing $\left(50^{\circ} \mathrm{C}\right)$ and 1 min extension $\left(72^{\circ} \mathrm{C}\right)$. AFLP reactions employed 2 oligonucleotide primers; M1 corresponding to the MseI ends and a radioactively labeled EcoRI primer (5'-GACTGCGTACCAATTN-3') corresponding to the ECoRI ends. The EcoRI primers had 1 selective nucleotide extension $(\mathrm{N}=\mathrm{G}, \mathrm{A}, \mathrm{T}$ or $\mathrm{C})$. In each reaction 1 selective ECoRI primer was employed. Four primer combinations were used to detect AFLP variation between isolates. The cycling parameters were as described for the preamplification reaction with the annealing time extended to $1 \mathrm{~min}$. Four $\mu \mathrm{l}$ of each sample was loaded into $6 \%$ denaturing polyacrylamide gels (8 M urea) and electrophoresed for $1.5 \mathrm{~h}$ at $2000 \mathrm{~W}$. The gels were then transferred onto chromatography paper, dried and a FUJI Medical X-Ray Film was exposed to them overnight (14 to $18 \mathrm{~h}$ ) at room temperature.

AFLPs were scored as presence (1) or absence (0) of a band in the polyacrylamide gels. The total number of amplified bands was scored for both polymorphic and monomorphic bands. The banding patterns of the 4 primer sets were combined and the pairwise similarities calculated using Jaccard's coefficient. Cluster analysis was performed on the resultant similarity matrix using the unweighted-pair group method with average linkage (UPGMA) (Sneath \& Sokal 1973)

\section{RESULTS}

The biochemical profiles of all isolates presented only minor differences to that described by Colorni et al. (2002), with some variability observed in the activity of $\beta$-glucuronidase and arginine dihydrolase, and in the fermentation of mannitol, amygdalin and melezitose.

\section{S rDNA sequencing}

16S rDNA sequences matched the sequences of Streptococcus iniae available in GenBank with 100 to $99 \%$ similarity. All Israeli marine isolates, 1 isolate from striped bass cultured in brackish water (s42), as well as the isolates from Barbados, USA, Canada, Australia and Japan shared 100\% sequence homology with ATCC 29178 (GenBank accession no. AF335572).

Two Israeli isolates from tilapia cultured in brackish water in 2 different locations (s29 and s41) exhibited a new 1-nucleotide variation, differing from Streptococcus iniae ATCC 29178 in 1 base in position number 593, reported as A in ATCC 29178 and substituted with a $\mathrm{T}$ in both isolates (GenBank accession no. AY260834). Six isolates from trout cultured in Upper Galilee (s36, s39, sD15, s404, s206 and s173) shared
$100 \%$ homology and were identical to other isolates from Israeli trout (GenBank accession no. AF335573), differing from ATCC 29178 in 6 bases.

\section{RAPD}

Using the RAPD technique, the isolates clustered into 2 groups. The first group included 5 Israeli freshwater isolates (s36, s39, s173, s206 and s404) which shared identical RAPD products, approximately 2500, 2000 and 1100 bp long (Fig. 1, Lane 1). The second group included 4 Israeli fresh/brackish water isolates (s29, s41, s42 and sD15) and all other isolates, which in addition to the 2500, 2000, and 1100 bp long PCR products, shared an extra RAPD product approximately 850 bp long (Fig. 1, Lane 2).

\section{AFLP}

The total number of AFLP bands per primer set ranged from 70 to 134 and summation of the bands of the 4 primer combinations revealed 483 distinct bands. A similarity matrix was produced using all 483 bands and a dendrogram was constructed (Fig. 2). All Streptococcus iniae isolates clustered at $90 \%$ similarity. The Israeli marine isolates grouped into one homogeneous subcluster, regardless of their origin, host or year of isolation, at $100 \%$ similarity (Subcluster A). The Israeli freshwater isolates grouped in a number of subclusters: isolate s36 (trout) diverged from all other isolates at $90 \%$ similarity; 4 isolates s39, s173, s206 and s404

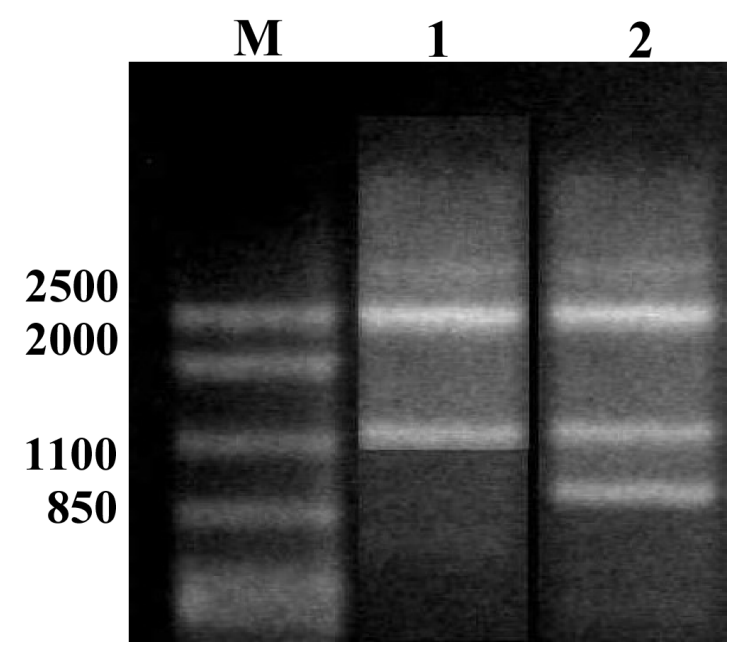

Fig. 1. Streptococcus iniae. RAPD patterns. Lanes: M, AmpliSize $^{\mathrm{TM}}$ molecular ruler (Bio-Rad); 1, patterns shared by 5 of the Israeli freshwater isolates (s36, s39, s173, s206 and s404); 2 , patterns shared by all other isolates. Numbers on the left indicate approximate $\mathrm{PCR}$ product size in $\mathrm{bp}$ 


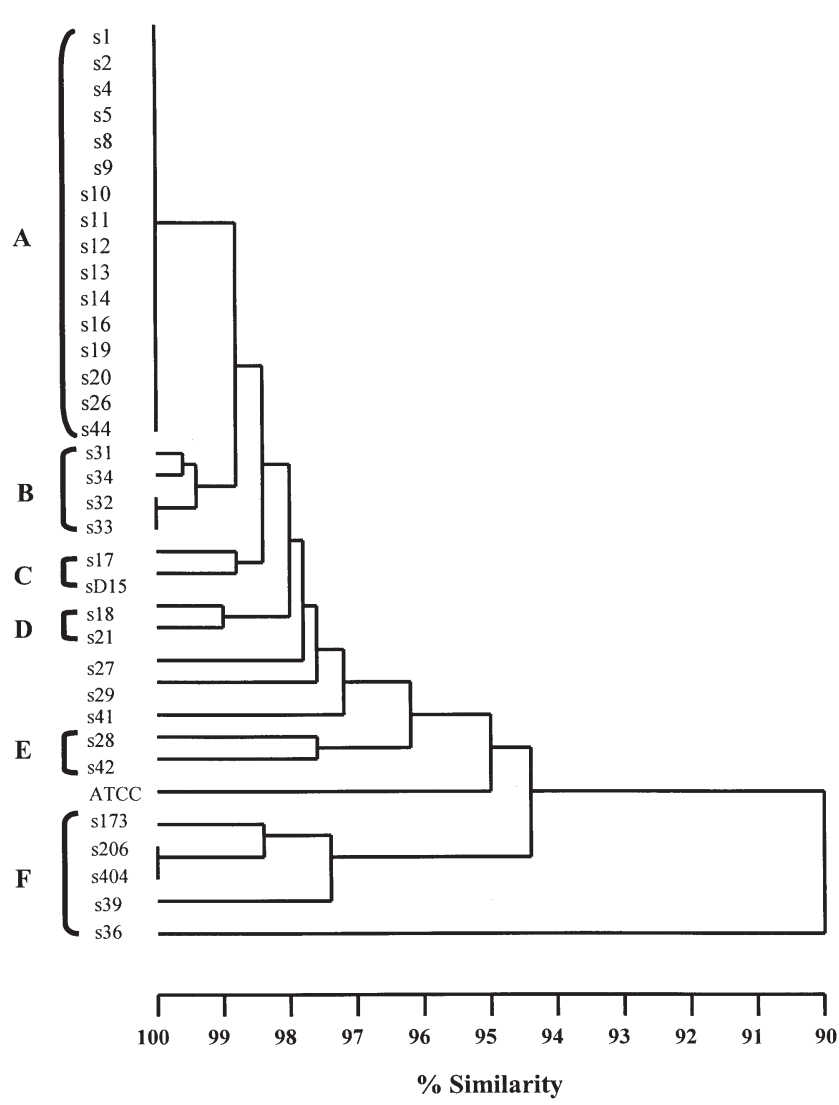

Fig. 2. Streptococcus iniae. AFLP derived from UPGMA cluster analysis: A to F: subclusters. ATCC: American Type Culture Collection S. iniae 29178

(trout) diverged at $94.5 \%$ similarity and shared 97.5 to $100 \%$ homology (Subcluster F); isolate s42 (striped bass) diverged at $96.2 \%$ similarity and grouped with isolate s28 (sole) from Japan (Subcluster E); isolate sD15 (trout) diverged at 98\% similarity and grouped with isolate s17 (tilapia) from New York State (Subcluster C); the 2 remaining isolates s41 and s29 (tilapia) diverged at 97.5 and $97.7 \%$ similarity, respectively. The isolates from Canada (s18, human) and North Dakota (s21, tilapia) diverged at 98\% similarity and shared $99 \%$ homology (Subcluster D). The isolate from Australia (s27, barramundi) and ATCC 29178 diverged at 97.8 and $95 \%$ similarity, respectively. The Barbados isolates s31, s32, s33 and s34 (feral fish) diverged at 98.6\% similarity (Subcluster B).

\section{DISCUSSION}

The biochemical profile of all the isolates is consistent with their identification as Streptococcus iniae. In addition, sequencing of approximately 600 bp PCR products from the $16 \mathrm{~S}$ rDNA allowed both the confirmation of species identification at the molecular level and the detection of a new 1-nucleotide variant. In the same region, Bachrach et al. (2001) reported 6 nucleotide variations, which enabled these authors to differentiate between Israeli freshwater isolates and the ATCC strain 29178. The apparent similarity of the Israeli marine isolates to those from countries as far away as the USA, Canada, Barbados, Japan and Australia is not surprising. Although the $16 \mathrm{~S}$ rDNA gene is still being widely used in bacterial identification, it has become increasingly clear that the homology of this gene is often too high to guarantee even species identity (Fox et al. 1992, Ucko et al. 2002). The RAPD and AFLP methods, on the other hand, demonstrated higher discriminative properties, the former differentiating among group A streptococci (Gardiner et al. 1995) and even $S$. iniae serotypes (Bachrach et al. 2001), and the latter among strictly related bacterial strains (Zabeau \& Vos 1993, Janssen et al. 1996, Blears et al. 1998, Kvitt et al. 2002).

The endonucleases EcoRI and MseI were chosen for AFLP, as this combination showed high discriminatory power among group A streptococci (Desai et al. 1998). RAPD did not reveal a $1400 \mathrm{bp}$ product observed in previous work (Colorni et al. 2002) in any of the isolates. However, in our and other investigators' (Meunier \& Grimont 1993) experience, difficulties in reproducibility in RAPD analysis often occur as a result of minor variations in PCR conditions, DNA quality and quantity. Furthermore, while it is possible that greater resolution might have been obtained if more primers had been used, RAPD only discriminated some Israeli freshwater isolates from all the other isolates, whereas AFLP allowed the grouping of the Israeli marine and freshwater isolates into distinct clusters. Single isolates from other geographic regions were separated into distinct entities, which could be grouped into subclusters of various degrees of homology. The AFLP pattern in the Red Sea isolates, erroneously reported in a previous paper (Colorni et al. 2002) to be identical to that of the ATCC 29178 reference strain, was in fact found to share only about $94 \%$ similarity with this strain (Fig. 2). The Israeli marine isolates grouped into 1 homogeneous cluster, although the isolates had been obtained in different years (1995 to 2001) from different species of fish, of wild (Red Sea) as well as cultured (both Mediterranean and Red Sea) origin. The distance between the clusters of the Israeli marine and freshwater isolates indicates that, in spite of biochemical and pathogenic similarities, the streptococcosis that has been afflicting the aquaculture industries in the 2 environments in recent years was caused by different strains. 
Using restriction fragment length polymorphism (RFLP) of 16S rDNA and of whole rRNA genes (ribotyping) from 20 isolates of Streptococcus iniae, Eldar et al. (1997) showed that Israeli isolates from tilapia and (with one exception) trout could be differentiated from USA $S$. iniae isolates from tilapia, and excluded the possibility of an epidemiological link between $S$. iniae freshwater isolates in the 2 countries. The possibility that the Israeli marine isolates belong to a strain endemic to the Red Sea region cannot be ruled out. However, lack of historical documentation of the disease in the area prior to 1996 and the detection of 2 other bacterial pathogens (Mycobacterium marinum and Lactococcus garvieae) over a period of a few years in wild fish populations in the Gulf of Eilat suggest that either a surge in their virulence has occurred or that their appearance is the result of recent introductions, possibly with allochthonous species of fish introduced for aquaculture (Colorni et al. 2002, 2003, Ucko et al. 2002).

Although Streptococcus iniae has been isolated mainly from poikilothermic aquatic animals, its ability to infect humans renders this bacterium a threat to consumers. There have been 11 confirmed cases of human illness so far (10 in Canada and 1 in Texas) all due to puncture wounds or injuries when handling $S$. iniae-contaminated fish (Weinstein et al. 1997). However, it is reasonable to presume that only certain strains pose a health risk. In fact, Fuller et al. (2001) reported that $S$. iniae virulence is associated with a distinct genetic profile and demonstrated differences between pathogenic and non-pathogenic isolates. According to Dodson et al. (1999), S. iniae isolated from fish and human cases are genetically different and can be distinguished by their different biochemical profiles. In the human isolate (s18) available to us, however, we found neither biochemical nor genotypic distinctions. In fact, in the AFLP analysis this isolate was clustered at high (97.8\%) homology with a piscine isolate (s21). Some biochemical variability was observed in our isolates. The most pronounced inconsistency was the ability to hydrolyse arginine, with 13 isolates being positive or weakly positive and 22 negative. Bachrach et al. (2001) and Barnes et al. (2003) found that arginine dehydrolase $(\mathrm{ADH})$ positive and $\mathrm{ADH}$ negative strains of $S$. iniae present distinct serological reactivity, presumably as a reflection of differences in capsular antigens. Although ADH activity may have taxonomic validity, in our study it could not be correlated specifically to any one cluster.

High phenotypic similarities among Streptococcus iniae strains and transfers of fish from one 'infected' region to another 'infected' region may cause crossinfections and complicate possible management options such as treatment, vaccination or genetic selec- tion of resistant fish lines. At the molecular level, however, strain variation is revealed and can be correlated to geographic endemism, even though the degree of heterology is not a function of geographic distance. In fact, our results show that homology in isolates from distant regions is often higher than that observed in isolates from the same region (e.g. Israel) but different environments (marine and fresh/brackish waters).

Acknowledgements. The technical assistance of Y. Shtupler is gratefully acknowledged. We are particularly indebted to the following colleagues who kindly provided us with their Streptococcus iniae isolates: Prof. P. R. Bowser, Cornell University, New York (s17), Dr. D. Low and Dr. J. Fuller, University of Toronto, Canada (s18), Dr. J. J. Evans, United States Dept. of Agriculture, Maryland, and Dr. P. H. Klesius, United States Department of Agriculture, Alabama (s21), Dr. E. S. Bromage, James Cook University, Townsville, Australia (s27), Dr. K. Kanai, Nagasaki University, Japan (s28), Dr. D. Zilberg, Ben Gurion University, Sede Boqer, Israel (s29, s41, s42), Prof. H. W. Ferguson and Gillian Dreczkowski, University of Stirling, Scotland (s31-34), Dr. Claudio Ghittino, Istituto Zooprofilattico Sperimentale, Perugia, Italy (s36), Dr. A. Eldar, Kimron Veterinary Institute, Bet Dagan, Israel (sD15, s173, s206, s404). This research was carried out at the Green-Keiser Fish Health Center, IOLR-NCM, Eilat, with the support of the Yad Hanadiv Fund and the Israel Ministry of National Infrastructures.

\section{LITERATURE CITED}

Austin B (1999) Emerging bacterial fish pathogens. Bull Eur Assoc Fish Pathol 19:231-234

Austin B, Austin DA (1999) Bacterial fish pathogens: disease of farmed and wild fish, 3rd edn. Springer-Verlag, Chichester

Bachrach G, Zlotkin A, Hurvitz A, Evans DL, Eldar A (2001) Recovery of Streptococcus iniae from diseased fish previously vaccinated with a Streptococcus vaccine. Appl Environ Microbiol 67:3756-3758

Barnes AC, Young FM, Horne MT, Ellis AE (2003) Streptococcus iniae: serological differences, presence of capsule and resistance to immune serum killing. Dis Aquat Org 53: 241-247

Berridge BR, Fuller JD, de Azavedo J, Low DE, Bercovier H, Frelier PF (1998) Development of specific nested oligonucleotide PCR primers for the Streptococcus iniae 16S-23S ribosomal DNA intergenic spacer. J Clin Microbiol 36:2778-2781

Blears MJ, De Grandis SA, Lee H, Trevors JT (1998) Amplified fragment length polymorphism (AFLP): a review of the procedure and its applications. J Ind Microbiol Biotechnol 21:99-114

Bromage ES, Owens L (2002) Infection of barramundi Lates calcarifer with Streptococcus iniae: effects of different routes of exposure. Dis Aquat Org 52:199-205

Colorni A, Diamant A, Eldar A, Kvitt H, Zlotkin A (2002) Streptococcus iniae infections in Red Sea cage-cultured and wild fishes. Dis Aquat Org 49:165-170

Colorni A, Ravelo C, Romalde JL, Toranzo AE, Diamant A (2003) Lactococcus garvieae in wild Red Sea wrasse Coris aygula (Labridae). Dis Aquat Org 56:275-278

Desai M, Tanna A, Wall R, Efstratiou A, George R, Stanley J (1998) Fluorescent amplified-fragment length polymor- 
phism analysis of an outbreak of group A streptococcal invasive disease. J Clin Microbiol 36:3133-3137

Dodson SV, Maurer JJ, Shotts EB (1999) Biochemical and molecular typing of Streptococcus iniae isolated from fish and human cases. J Fish Dis 22:331-336

Eldar A, Bejerano Y, Bercovier H (1994) Streptococcus shiloi and Streptococcus difficile: two new streptococcal species causing a meningoencephalitis in fish. Curr Microbiol 28: 139-143

Eldar A, Frelier PF, Assenta L, Varner PW, Lawhon S, Bercovier H (1995) Streptococcus shiloi, the name for an agent causing septicemic infection in fish, is a junior synonym of Streptococcus iniae. Int J Syst Bacteriol 45:840-842

Eldar A, Frelier PF, Asanta L, Varner PW, Lawhon S, Bercovier H (1997) DNA restriction length polymorphism of rRNA genes (ribotyping) allows distinction between Israeli and US $S$. iniae trout and tilapia isolates. FEMS Microbiol Lett 151:155-162

Ferguson HW, St John VS, Roach CJ, Willoughby S, Parker C, Ryan R (2000) Caribbean reef fish mortality associated with Streptococcus iniae. Vet Record 147:662-664

Fox GE, Wisotzkey JD, Jurtshuk P Jr (1992) How close is close: $16 \mathrm{~S}$ rRNA sequence identity may not be sufficient to guarantee species identity. Int J Syst Bacteriol 42:166-170

Fuller JD, Bast DJ, Nizet V, Low DE, de Azavedo JCS (2001) Streptococcus iniae virulence is associated with a distinct genetic profile. Infect Immun 69:1994-2000

Gardiner D, Hartas J, Currie B, Mathews JD, Kemp DJ, Sriprakash KS (1995) Vir-typing: a long-PCR typing method for group A streptococci. PCR Methods Appl 4: 288-293

Janssen P, Coopman R, Huys G, Swings J, Bleeker M, Vos P, Zabeau M, Kersters K (1996) Evaluation of the DNA fingerprinting method AFLP as a new tool in bacterial taxonomy. Microbiology 142:1881-1893

Kitao T (1993) Streptococcal infections. In: Inglis V, Roberts

Editorial responsibility: Carey Cunningham,

Aberdeen, UK
RJ, Bromage NR (eds) Bacterial diseases of fish. Blackwell, Oxford, p 196-210

Kusuda R, Komatsu I (1978) A comparative study of fish pathogenic Streptococcus isolated from saltwater and freshwater fishes. Nippon Suisan Gakkaishi 44:1073-1078

Kvitt H, Ucko M, Colorni A, Batargias C, Zlotkin A, Knibb W (2002) Photobacterium damselae ssp. piscicida: detection by direct amplification of $16 \mathrm{~S}$ rRNA gene sequences and genotypic variation as determined by amplified fragment length polymorphism (AFLP). Dis Aquat Org 48:187-195

Meunier JR, Grimont PA (1993) Factors affecting reproducibility of random amplified polymorphic DNA fingerprinting. Res Microbiol 144:373-379

Neeman R, Keller N, Barzilai A, Korenman Z, Sela S (1998) Prevalence of internalisation-associated gene, prtF1, among persisting group-A streptococcus strains isolated from asymptomatic carriers. Lancet 352:1974-1977

Sneath PHA, Sokal RR (1973) Numerical taxonomy: In: WH Freeman (ed) The principles and practice of numerical classification, 2nd edn. WH Freeman, San Francisco

Ucko M, Colorni A, Kvitt H, Diamant A, Zlotkin A, Knibb WR (2002) Strain variation in Mycobacterium marinum fish isolates. Appl Environ Microbiol 68:5281-5287

Vos P, Hogers R, Bleeker M, Reijans M and 7 others (1995) AFLP: a new concept for DNA fingerprinting. Nucleic Acids Res 21:4407-4414

Weinstein MR, Litt M, Kertesz DA, Wyper P and 8 others (1997) Invasive infections due to a fish pathogen, Streptococcus iniae. New Engl J Med 337:589-594

Zabeau M, Vos P (1993) Selective restriction fragment amplification: a general method for DNA fingerprinting. Publication 0534858 A1, European Patent Office Bulletin 93/13, Munich

Zlotkin A, Hershko H, Eldar A (1998) Possible transmission of Streptococcus iniae from wild fish to cultured marine fish. Appl Environ Microbiol 64:4065-4067

Submitted: September 29, 2003; Accepted: March 1, 2004 Proofs received from author(s): September 1, 2004 